\title{
THREATS AND INTERNATIONAL TOOLS FOR SUSTAINABLE BROWN BEAR (Ursus arctos L.) MANAGEMENT
}

\author{
VUKAN LAVADINOVIĆ , ZORAN POPOVIĆ², ZORAN RISTIĆ ${ }^{3}$, DEJAN BEUKOVIĆ \\ ${ }^{1}$ Faculty of Environment and Natural Resources, Albert-Ludwig University of Freiburg, Tennenbacherstr, 4, D- \\ 79106, Germany; e-mail: vukanlavadinovic@yahoo.com \\ ${ }^{2}$ Faculty of Agriculture, University of Belgrade, Nemanjina 6, 11080 Belgrade-Zemun, Serbia \\ ${ }^{3}$ Faculty of sciences, University of Novi Sad, Trg Dositeja Obradovića 3, 21000 Novi Sad, Serbia \\ ${ }^{4}$ Faculty of Agriculture, University of Novi Sad, Trg Dositeja Obradovića 8, 21000 Novi Sad, Serbia
}

\begin{abstract}
Lavadinović V., Popović Z., Ristić Z., Beuković D.: Threats and international tools for sustainable brown bear (Ursus arctos L.) management. Ekológia (Bratislava), Vol. 32, No. 4, p. 345-351, 2013.

Negative relation between humans and large carnivores with unprofitable management caused a decrease in abundance of the latter within their natural habitat. Main reasons for negative attitudes of humans towards large carnivores are damages, fear and unfamiliarity with their characteristics. Brown bear (Ursus arctos) is a European autochthonous large carnivore. Although it is not threatened at the global level, its abundance in Europe is limited to several populations. Protection has an important role in brown bear conservation, since they face different threats, mainly by negative human activities. Conservation of the brown bear is complicated due to its habitats overlapping with the human environment and also because brown bears require large territories. In order to protect brown bears more efficiently, it is important to identify the threats and to conduct the species protection by international recommendations and agreements. In this paper, we analysed brown bear distribution in Europe, abundance limitation factors and international conservation instruments.
\end{abstract}

Key words: brown bear, abundance, threats, international management tools.

\section{Introduction}

The bear family Ursidae is characterised by the adaptability to various habitat conditions. Today, eight extant representatives of this family are distributed in more than 60 countries on four continents (Servheen et al., 1999). The range of bear distribution is highly diverse, from Equatorial tropical forests, through broadleaf and coniferous forest ecosystems, to Arctic tundras (Curry-Lindhal, 1972; Mattson, Knight, 1989; Kolter, Zander, 1997; Swenson et al., 2000). In addition to their wide range of distribution, bears are distinguished by diverse diets (Hamer et al., 1991; Clevenger et al., 1992; Murphy et al., 2003), thanks to which they are readily adaptable to various habitats. Of all the representatives of the family Ursidae, brown bear (Ursus arctos) has the widest distribution, covering three continents (Taberlet, Bouvet, 1994; Swenson et al., 2000; Wultsch, 2004; Paunović et al., 2007). Therefore, it is considered as one of the most widespread terrestrial animals (www.iucnredlist.org). Brown bear is the only 
species in the family Ursidae which inhabits Europe (Länderübergreifende Koordinierungsstelle für Bärenfragen, 2005).

Natural range of brown bear includes North America, parts of Northern Mexico, Europe, Asia Minor, parts of North Africa and the Asian continent (www.iucnredlist.org). Despite its adaptation to different habitat types and diverse diets, its abundance decreases drastically and therefore it is suppressed from many areas. Although the traces of human fascination with brown bear can be found in many myths and legends, pagan religions, names of towns and personal names, or on the arms of many European nations (Swenson et al., 2000), in some regions bears have become a threatened game species as a result of adverse human activities. Direct and indirect negative factors caused the reduction in brown bear density (Curry-Lindhal, 1972; Zager et al., 1983; Mattson et al., 1987; McLellan, Shackleton, 1988; Dahle, Swenson, 2003), which has been halved at the global level since the middle of the $19^{\text {th }}$ century (Servheen, 1989, 1990; Taberlet, Bouvet, 1994; Wultsch, 2004).

Brown bear is not listed as a threatened species at the global level (www.iucnredlist.org), although its distribution in natural habitats in Europe has decreased drastically (Swenson et al., 2000; Wultsch, 2004). Brown bear population on the European continent can be divided into the population in Russia, and a much lower number of individuals in other European countries (Swenson et al., 2000). Bear populations in Europe (outside Russia) are isolated (Taberlet, Bouvet, 1994; Swenson et al., 2000); consequently, special attention has to be devoted to their protection. For this reason, many European countries are focused on the conservation and augmentation of the extant brown bear populations.

\section{Abundance of brown bear populations in Europe}

Based on historical data, brown bears occurred throughout Europe, except on islands such as Ireland, Iceland, Corsica and Sardinia (Swenson et al., 2000). Today, they are found in Europe in several isolated populations identified by Swenson et al. 2000. The largest continuous brown bear population in Europe is the north-eastern population, estimated at about 37,500 bears. The population stretches from the Ural Mountains in the east to the Finland coast in the west, encompassing the territories of Russia, Estonia, Lithuania, Latvia and Finland. In the north of Europe, the Scandinavian population which inhabits Norway and Sweden is estimated at 1000 individuals. The Carpathian population, which is considered as the second largest in Europe, is estimated at 8000 individuals occurring in Slovakia, Romania, Poland and Ukraine. The abundance of Alps-Dinaric-Pindos population is estimated at 2800 bears, which inhabit the territory of south-eastern Austria, north-eastern Italy, the former SFR Yugoslavia, Albania and Greece. In Bulgaria, there are two populations, Rila-Rhodope population, which covers the area of northern Greece, and Stara Planina population. Both populations consist of a few hundreds of individuals. In addition to these populations, in Europe there are several smaller populations in the Cantabrian and Apennine Mountains, Alps and Pyrenees. The abundance of these populations is estimated at a few tens of individuals (Swenson et al., 2000).

Brown bear abundance in Serbia is estimated at 53 individuals (Paunović et al., 2007), which live in isolated populations in eastern and western parts of Serbia. Although Serbia be- 
longs to Alps-Dinaric-Pindos population (Swenson et al., 2000), some individuals in southwestern Serbia originate from the Bulgarian Stara Planina population (Paunović et al., 2007), and it is also possible that the individuals from the Carpathian population migrate to eastern parts of Serbia, although this theory has not been confirmed.

\section{Threats}

Brown bear is a species adaptable to different habitat conditions which resulted in its very wide range. Thanks to the adverse anthropogenic effects, its population has been suppressed to forest complexes which offer, in addition to food and shelter, the necessary tranquillity (Swenson et al., 2000). For this reason, it can be concluded that survival of brown bears depends predominantly on the coexistence with humans, i.e. their direct and indirect effects. Habitat loss and fragmentation, deprivation of food sources, harvesting, poaching, disturbance and isolation are some of the examples of negative anthropogenic activities (CurryLindhal, 1972; Zager et al., 1983; Mattson et al., 1987; McLellan, Shackleton, 1988; Swenson et al., 2000; Dahle, Swenson, 2003; Paunović et al., 2007). Brown bear, because of its longdistance movements, is under the adverse impact of road infrastructure, because the increase in the road network density causes decrease in bear abundance in the area (Elgmork, 1978). The road infrastructure directly or indirectly affects the habitat fragmentation, lowers the reproduction success, increases mortality, pollution, species distribution, population density and traffic accidents (Reed et al., 1996; Swenson et al., 2000; Troumbulak, Frissel, 2000; Corlatti et al., 2009). In addition to harmful human-induced activities which are generally shown towards the majority of large wild mammals, there is also human aversion to bears because of the inflicted damage or because of fear of bear's presence. Bears can attack livestock, destroy beehives, damage fruit trees and crops and in some cases attack people, although rarely and in specific situations (Popović, Đorđević, 2010; Popović et al., 2006; Swenson et al., 2000; Paunović et al., 2007). The value of damage caused by bear in Bosnia and Hercegovina (BH) increased in the past years, and the officially registered value of damage in 2006 amounted to more than KM16000/€8000 (Adamič et al., 2006). For this reason, bears can be at a higher risk from poaching than other species.

In addition to adverse human-induced effects, bear abundance is also affected by biotic and abiotic factors. Based on the study in Slovakia (Rigg, Adamec, 2007), brown bear mortality caused by the above factors is very low. Although bear has almost no natural enemies except humans, in rare cases the young cubs are preyed upon by predators such as wolves (Vaisfeld, Chestin, 1993). Still, due to their low reproduction capacity, the above factors are also significant for the conservation of brown bear abundance.

\section{Legal measures of protection}

Although brown bear is not threatened at the global level (www.iucnredlist.org), the species conservation is covered by a great number of action plans, because it is endangered in some regions. The reason for concern about brown bear abundance and distribution is based on its specific coexistence with people, which has caused a drastic reduction in its abundance 
(Servheen, 1989, 1990; Taberlet, Bouvet, 1994; Wultsch, 2004). Brown bear protection can be multi- beneficial, because this species is distinguished by migrant periods and wide habitats; consequently, in the protection of animal species, it is often specified as umbrella species (Wultsch, 2004).

At the international level there are several multilateral documents that indirectly regulate brown bear conservation. The Earth Summit was followed by the Biological Diversity Convention and its Article 8 instructs the Contracting Parties to include the measures for in situ protection in their national plans. This method of protection supports the adoption of action plans or long-term strategies for the conservation of threatened game species. At the same time, Agenda 21 was developed and adopted. It supports the Biological Diversity Convention, and by its chapter 15, promotes the protection of threatened carnivores. In addition to the above two documents, at the international level, the Convention on International Trade in Endangered Species of Wild Fauna and Flora (CITES) defines bear as a potentially threatened species (Wultsch, 2004).

A very important role in brown bear conservation at the international level is performed by two non-governmental organisations (Wultsch, 2004) - the International Union for the Conservation of Nature and Natural Resources (IUCN) and the World Wide Fund for Nature (WWF). After Machado, 1997, at the international level, IUCN is the most influential organisation for the protection of threatened animal species. The Species Survival Commission (SSC), developed under IUCN, consists of an international team of scientific experts in different fields aiming at the development of action plans based on the assessment of species abundance, its distribution and habitat factors (SPECIES SURVIVAL COMMISSION, 2000). From 1986, the SSC developed the Action Plan for the Conservation of the Brown Bear in Europe, and in 1999, IUCN published the document Status Survey and Conservation Action Plan. This document includes eight bear species, including brown bear (Servheen et al., 1999).

WWF is also a very active organisation at the international level. It launched the Large Carnivore Initiative for Europe (LCIE). The aim of this initiative is the inclusion of government institutions, scientists, landowners, forest owners and international organisations in the conservation of large carnivores in Europe (Zedrosser et al., 2001).

In Europe at the international level, there are several documents which affect the brown bear conservation. The Bern Convention is a crucial instrument in environmental conservation (www.coe.int), aiming at the conservation of flora and fauna on the European continent and in some countries of North Africa. Pursuant to the Bern Convention, the brown bear is a strictly protected species, but this Convention does not provide direct measures for the species conservation; it rather recommends a framework of general measures which should be taken by each contracting party (Wultsch, 2004).

At the European Union level, the EU Directive 92/43/EEC, known as the Habitats Directive, is one of the principal mechanisms for protecting endangered species of flora and fauna through sustainable habitat development. It defines the need for specially protected areas for the conservation of brown bear distribution in the European Union (Wultsch, 2004). In Europe, at the regional level, the Carpathian Convention was adopted by six Central and Eastern European countries which manage brown bear on their territories: 
the Czech Republic, Hungary, Poland, Romania, Slovakia, Ukraine and Romania. The aim of this Convention is the conservation of the Carpathians, as the unique ecosystem which is the habitat for several species of large carnivores (Bennett, 2000). In 2000, IUCN published the 'Action Plan for the Conservation of the Brown Bear in Europe' which identifies brown bear populations in Europe, assesses their abundance and analyses the major threats (Swenson et al. 2000). This study is based on national assessments of brown bear distribution and population numbers. In addition to this comprehensive study for the European continent, there are several regional action plans dealing with brown bear conservation, such as the 'Large Carnivore Action Plan for Dinara-Pindus range' and 'Action Plan for the Baltic Large Carnivore Initiative’.

In addition to international conventions, directives and bilateral agreements, many European countries adopted, at the national level, action plans for the conservation of brown bear abundance and sustainable management. The trend of bear conservation action plans started especially in western and central European countries, but it extended also to other European countries. Most documents are initiated through international agreements, such as the Bern Convention, or the Habitats Directive, and a few are based on national legislation on nature conservation, or developed through local NGOs (Wultsch, 2004). Action plans differ depending on the country, as the threats to brown bear vary among the European countries, and among different bear populations. The legal status of brown bear varies among the European countries: In Serbia, brown bear is a permanently protected species, and in the neighbouring Romania, it is a protected species. Furthermore, the brown bear legal status and the legal jurisdiction of the laws can vary also within a country, as is the case in Austria (Länderübergreifende Koordinierungsstelle für Bärenfragen, 2005).

\section{Conclusion}

Although according to IUCN research, brown bear is not threatened at the global level, its distribution and abundance varies in European countries. Brown bear has been suppressed from most of its native habitats in Europe, and consequently there remained only a few stable populations which inhabit mainly northern and eastern parts of the continent. As the brown bear is distinguished by migrating patterns, it is considered as an umbrella species in nature protection, and the importance of its conservation has been recognised. Also, the conservation of this species is motivated by general sympathies, based on human fascination with bear. Still, thanks to its habitat overlapping with human environment, the problem of brown bear abundance must be seriously analysed. Brown bear has few natural enemies and it is exceptionally adapted to habitat conditions; therefore all threats, either direct or indirect, originate from the adverse anthropogenic effects. The harmonisation of the coexistence of humans and bear requires constant public education, as well as the analysis of public opinion regarding the increase in the brown bear abundance. However, the priority in all bear reintroductions is primarily human security.

The adequate protection of brown bear is defined and enforced by the international conventions, which, together with the expert activities of nongovernmental organisations such 
as IUCN and WWF and the European Union Directive, provide the guidelines for the professional management of this species. The adequate brown bear protection must be carried out at the national level, supported by regional cooperation in agreement with the international instructions. In this way, the sustainable management of this species can be assured.

\section{Acknowledgements}

This paper was realized as part of the project Establishment of Wood Plantations Intended for Afforestation of Serbia (31041) financed by the Ministry of Education and Science of the Republic of Serbia within the framework Technological development for the period 2011-2014.

\section{References}

Adamič, M., Rapaić, Ž., Popović, Z., Kunovac, S., Koprivica, M., Soldo, V., Marković, B., Maunaga R., Mićević, M. \& Ilić V. (2006). Ugrožene vrste divljači u Bosni i Hercegovini. Finalni izveštaj. Banja luka.

Bennett, G. (2000). The Carpathian Ecoregion initiative. Danube-Carpathian Programme, WWF-International.

Clevenger, A.P., Purroy, F.J. \& Pelton M.R. (1992). Food habits of brown bears (Ursus arctos) in the Cantabrian Mountains, Spain. J. Mammal., 73(2), 415-421.

Corlatti, L., Hackländer, K. \& Frey-Roos F. (2009). Ability of wildlife overpasses to provide connectivity and prevent genetic isolation. Conserv. Biol., 23(3), 548-556.

Council of Europe - Culture, heritage and nature (2011). Bern convention on the conservation of European wildlife and natural habitats. [on-line] (Updated 2011). Available at: http://www.coe.int/t/dg4/cultureheritage/nature/ bern/default_en.asp [Accessed on 8 August 2011].

Curry-Lindhal, K. (1972). The brown bear (Ursus arctos) in Europe: decline, present distribution, biology and ecology. International Conf. Bear Res. and Manage., 2, 74-80.

Dahle, B. \& Swenson J.E. (2003). Home ranges in adult Scandinavian brown bears (Ursus arctos): effect of mass, sex, reproductive category, population density and habitat type. J. Zool., 260(4), 329-335.

Elgmork, K. (1978). Human impact on a brown bear population (Ursus arctos L.). Biol. Conserv., 13(2), 81-103.

Hamer, D., Herrero, S. Brady K. (1991). Food and habitat used by Grizzly Bears, Ursus arctos, along the Continental Divide in Waterton Lakes National Park, Alberta. Can. Field-Nat., 105(3), 325-329.

IUCN (2011). IUCN Red List of Threatened Species - Ursus arctos. Version 2011.1. [on-line] (Updated on 16 June 2011). Available at: http://www.iucnredlist.org/apps/redlist/details/41688/0 [Accessed on 30 June 2011].

Kolter, L. \& Zander R. (1997). Potential and limitations of environmental enrichment in managing behavioural problems of polar bears. In 2. International Conference on Environmental Enrichment, 21-25 Aug 1995. Copenhagen.

Länderübergreifende Koordinierungsstelle für Bärenfragen (2005). Managementplan Bär Österreich - überarbeitete Version 2005. Wien: WWF Österreich.

Machado, A. (1997). Guidelines for action plans for animal species: planning recovery. Strasbourgh: Council of Europe Publishing.

Mattson, D.J. \& Knight R.R. (1989). Evaluation of grizzly bear habitat using habitat type and cover type classifications. General technical report INT - U.S. Department of Agriculture, Forest Service, Intermountain Research Station.

McLellan, B.N. \& Shackleton D.M. (1988). Grizzly bears and recourse-extration industries: effects of roads on behaviour, habitat use and demography. J. Appl. Ecol., 25(2), 451-460. http://www.jstor.org/stable/2403837

Murphy, A., Waits, L.P. \& Kendall K.C. (2003). The influence of diet on faecal DNA amplification and sex identification in brown bears (Ursus arctos). Mol. Ecol., 12(8), 2261-2265.

Paunović, M., Ćirović, D. \& Milenković M. (2007). Akcioni plan za očuvanje mrkog medveda Ursus arctos, L., 1758 u Srbiji. Faza 1 - Strateški plan. Beograd: Biološki fakultet Univerziteta u Beogradu.

Peter Zager, P., Jonkel, C. \& Habeck J. (1983). Logging and wildfire influence on grizzly bear habitat in Northwestern Montana. International Conf. Bear Res. and Manage., 5, 124-132.

Popović, Z. (2006). Štete od divljači na šumskim i poljoprivrednim kulturama. Glasnik Šumarskog Fakulteta Univerziteta u Banjoj Luci, 6, 51-64.

Popović, Z. \& Đorđević N. (2010). Gazdovanje populacijama divljači u cilju smanjenja šteta. Beograd: Poljoprivredni fakultet Univerziteta u Beogradu. 
Reed, R.A., Johnson-Barnard, J. \& Baker W.L. (1996). Contribution of roads to forest fragmentation in the rocky mountains. Conserv. Biol., 10, 1098-1106.

Rigg, R. \& Adamec M. (2007). Status, ecology and management of the brown bear (Ursus arctos) in Slovakia. Liptovský Hrádok: Slovak Wildlife Society.

Servheen, C., Herrero, S. \& Peyton B. (1999). Bears. Status Survey and Conservation Action Plan. IUCN/SSC Bear and Polar Bear Specialist Groups. Switzerland and Cambridge: IUCN Gland.

Servheen, C. (1989). The status and conservation of the bears of the world. In Proceedings of $8^{\text {th }}$ International Conference on Bear Research and Management. British Columbia: Victoria.

Servheen, C. (1990). The status and conservation of brown bears of the world. In International Conference of Bear Research and Management Monograph Series No. 2.Species Survival Commission (2000). Strategic Plan 2001-2010. Gland: IUCN.

Swenson, J.E., Gerstl, N., Dahle, B. Zedrosser A. (2000). Action plan for the conservation of the brown bear (Ursus arctos) in Europe. Strasbourgh: Council of Europe Publishing.

Taberlet, P. Bouvet J. (1994). Mitochondrial DNA polymorphism, phylogeography, and conservation genetics of the brown bear Ursus arctos in Europe. Proc. R. Soc. Lond. B, 255(1344), 195-200.

Troumbulak, S.C. \& Frissell C.A. (2000). Review of ecological effects of roads on terrestrial and aquatic communities. Conserv. Biol., 14, 18-30.

Vaisfeld, M.A. Chestin I.E. (1993). Bears: brown bear, polar bear, Asian black bear; distribution, ecology, use and protection. Moscow: Nauka.

Wultsch, C. (2004). Brown bear management plans in Europe and the continental United States. Master's thesis, Karl-Franzens-Universität, Graz.

Zedrosser, A., Gerstl, N. \& Rauer G. (1999). Brown bears in Austria. Federal Environment Agency-Austria. Monograph Series No.117. Vienna, Austria.

Zedrosser, A., Dahle, B., Swenson, J.E. \& Gerstl N. (2001). Status and management of the brown bears in Europe. Ursus, 12, 9-20. 